Article Type: Research Paper

\title{
COVID-19 and Stock Market Reaction in Indonesia
}

\author{
Yanuar Trisnowati ${ }^{1} *$ and Arianto Muditomo ${ }^{2}$
}

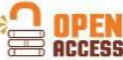 \\ AFFILIATION: \\ ${ }^{1,2}$ School of Business IPB \\ University, West Java, Indonesia.}

\section{*CORRESPONDENCE:}

yanuartrisnowati@apps.ipb.ac.ic

THIS ARTICLE IS AVALILABLE IN:

http://journal.umy.ac.id/index.php/ai

DOI: 10.18196/jai.v22i1.8859

\section{CITATION:}

Trisnowati, Y., \& Muditomo, A. (2021). COVID-19 and Stock Market Reaction in Indonesia. Journal of Accounting and Investment, 22(1), 23-36.

\section{ARTICLE HISTORY}

Received:

19 May 2020

Revised:

04 Sep 2020

02 Oct 2020

10 Nov 2020

Accepted:

25 Nov 2020

\begin{abstract}
:
Research aims: COVID-19 Pandemic happens all over the world. Pandemic impact hits almost all elements of life, one of the affected real sectors is finance especially the stock market. This research is aimed to present the reaction of the equity market in Indonesia towards the COVID-19 pandemic

Design/Methodology/Approach: The research method that is used is the study to examine market reaction towards the pandemic and abnormal return around the occurrence by using two methods; mean-adjusted abnormal return and market model.
\end{abstract}

Research findings: From the research conducted over the 10 indicators of the stock market index in Indonesia, it is concluded that 8 industrial sectors that have tenacious reaction toward the COVID-19 pandemic hit in Indonesia, where it is also found that the agriculture sector; basic and chemical industry; miscellaneous, consumer goods; property and real estate; transport and infrastructure; finance; trade, service, and investment, give stronger reactions compared with mining and manufacture.

Theoretical contribution/Originality: Researches about the stock market reaction to the non-economy phenomenon have already been carried out, but the research that is specifically done to study sectoral index reaction towards the non-economy occurrences is still wide open to doing for deeper research. Practitioner/Policy implication: This research can be important information for investors to understand the behavior of stock market efficiency in Indonesia in making decisions of investment

Research limitation/Implication: Non-economy event that becomes the subject of research is the COVID-19 pandemic that appeared and escalated fast all over the world. The researcher conducted the research and presented it as quickly as possible since the time is limited. It is meant to show a systematic and scientific thinking framework in addressing the non-economy events, but still in the context of reliability on the result of research to the same topic about the COVID-19 effect in other countries.

Keywords: COVID-19; Event-study; Indonesia Stock Market; Mean-Adjusted Abnormal Return; Market Model

\section{Introduction}

In the stock exchange or stock market, trading activity frequency is one of the elements that becomes the material to see the market reaction towards information that comes in the stock market (Taslim \& Wijayanto, 2016). 
The increase of frequency in trading transactions caused by high demand will push the stock price to ascend so the return will also be increasing. It is also able to increase the volume of trading transactions. The big trading volume shows that stock is preferred by investors. The investor tendency is to get interested in stocks that give high returns even if it is risky (Taslim \& Wijayanto, 2016).

COVID-19 has become a world pandemic, counted globally from 27 September 2020, it has been stated that 32.730.945 COVID-19 cases are confirmed, including 991.224 deaths, reported by WHO (WHO, 2020). In Indonesia, the corona firstly appeared in March. This was stated by the President of Indonesia; Joko Widodo in his speech in the presidential palace, Jakarta, on 2 March 2020. President Jokowi said that two people that went positively affected by Coronavirus were Japanese citizens who came to Indonesia. Up to 27 September 2020 cases that confirmed positive in Indonesia reached 275.213 with the recovered patients are at the number of 203.014 and 10.386 casualties (Official Prevention Unit of COVID-19, 2020). Since the Coronavirus (COVID-19) was found and escalated from the regional crisis in Hubei province, China, that later became a global pandemic, stock market collapse and market volatility went rising high in the world. It even happened in the United States of America's market. The volatility level stock market in the middle of March 2020 has surpassed the biggest volatility condition ever happened in October 1987 and December 2008 which occurred at the end of 1929 and early 1931 (Baker, Bloom, Davis, Kost, Sammon, \& Viratyosin, 2020). This COVID-19 pandemic can be classified as 'black swan' since it has economic consequences that are disadvantageous, as Taleb (2005) stated that a black swan is a random event with three characteristics: big impact, uncountable probability, and surprising effect (AlAli, 2020).

The COVID-19 pandemic caused panic for investors. This was evident from the decline of the IHSG which occurred from March 5 to March 9 by 6 percent. The Financial Services Authority (OJK) immediately responded by issuing a policy of movement of the Composite Stock Price Index (IHSG) and allowing the implementation of share repurchases issued by issuers (buyback) without obtaining approval from the General Meeting of Shareholders (RUPS). The issued regulation is contained in OJK Regulation No. 3 / SEOJK.04 / 2020 dated 9 March 2020 concerning Other Conditions as Market Conditions That Fluctuate Significantly in the Implementation of Shares Buyback Issued by Issuers or Public Companies.

Several studies have been found on the impact of COVID-19 on stock market returns, including the impact of the announcement of the first COVID-19 incident and the impact on the stock market (AlAli, 2020; Alam, Alam, \& Chavali, 2020; Bash, 2020; Huo \& Qiu, 2020), the impact of the pandemic on the Chinese stock market and specifically the characteristics of different companies/sectors in the Chinese stock market (He, Sun, Zhang, \& Li, 2020; Huo \& Qiu, 2020; Xiong, Wu, Hou, \& Zhang, 2020 ), the specific effect of the number confirmed COVID-19 cases on stock market returns in several countries (Ashraf, 2020; Liu, Manzoor, Wang, Zhang, \& Manzoor, 2020; Ruiz Estrada \& Lee, 2020; Zeren \& Hizarci, 2020). From previous studies, it is found that the result of this study generally presents a stock market reaction which is indicated by the average change of 
abnormal returns that went descending as the result of the first COVID-19 announcement at the stock markets in several countries.

Based on the result review of the previous studies, the researcher considers that it is necessary to examine the reaction of the Indonesian stock market as a result of the official government announcement when the first case of COVID-19 appeared in Indonesia on March 2, 2020, through abnormal return measurement proxy in the days before and after the announcement of the first COVID-19 case. The research gap that we found was that until the time this research was conducted there had not been any similar research in Indonesia. Moreover, we chose the index variable for each sector as the independent variable whose reaction to the announcement of the first case of COVID-19 was measured as the dependent variable. Research and presentation of this study's result will provide an empirical contribution related to the Indonesian stock market efficiency test through the average change proxy of abnormal return on the noneconomic events, both domestically and globally.

\section{Literature Review and Hypothesis Development}

In social science, the studies of events or more popularly known as event-studies have been widely carried out in a context that is related to economics and finance. Event studies are often used to measure the efficiency of the stock market in a semi-strong form. An efficient market is called a semi-strong-form efficiency if no single investor gets an abnormal rate of return through any information that is publicly available and is commonly tested by "event-studies". An event study in the stock market sector is a study conducted empirically to analyze the impact of an event on the capital market of a country (Suganda, 2018).

The COVID-19 pandemic event is not an economic event (non-economic event). Research related to event-studies for non-economic event and stock market reaction in Indonesia has been carried out, including political event happened on July 27, 1996 (Suryawijaya \& Setiawan, 1998), the inauguration of the President (Asshodiqi, 2016; Pratama, Sinarwati, \& Dharmawan, 2015), General Election (Luhur, 2010), Regional Head election (Wardhani, 2012), change of state officers (Islami \& Sarwoko, 2012), to natural events/phenomena like a flood (Luhur, 2010; Yuwono, 2013), social, changes in fuel price (Andarini \& Rahardjo, 2016; Ningsih \& Cahyaningdyah, 2014), terrorism (Sari, 2007; Utama \& Hapsari, 2012), to the issuance of government regulation and/or policy (Nanda \& Saryadi, 2017; Wibowo, 2017 ), etcetera.

Another research is also found that observes the economic impact on each pandemic phase (Figure 1) from the beginning of the first case up to the period after the pandemic (Barua, 2020). It also stated that the pandemic period would impact the supply chain performance (Narjoko, 2020) because the social and physical distancing is applied. This is such an interesting one to observe since the industrial sector in the supply chain becomes the dominant economic mover for all this time. 
Trisnowati \& Muditomo

COVID-19 and Stock Market Reaction in Indonesia

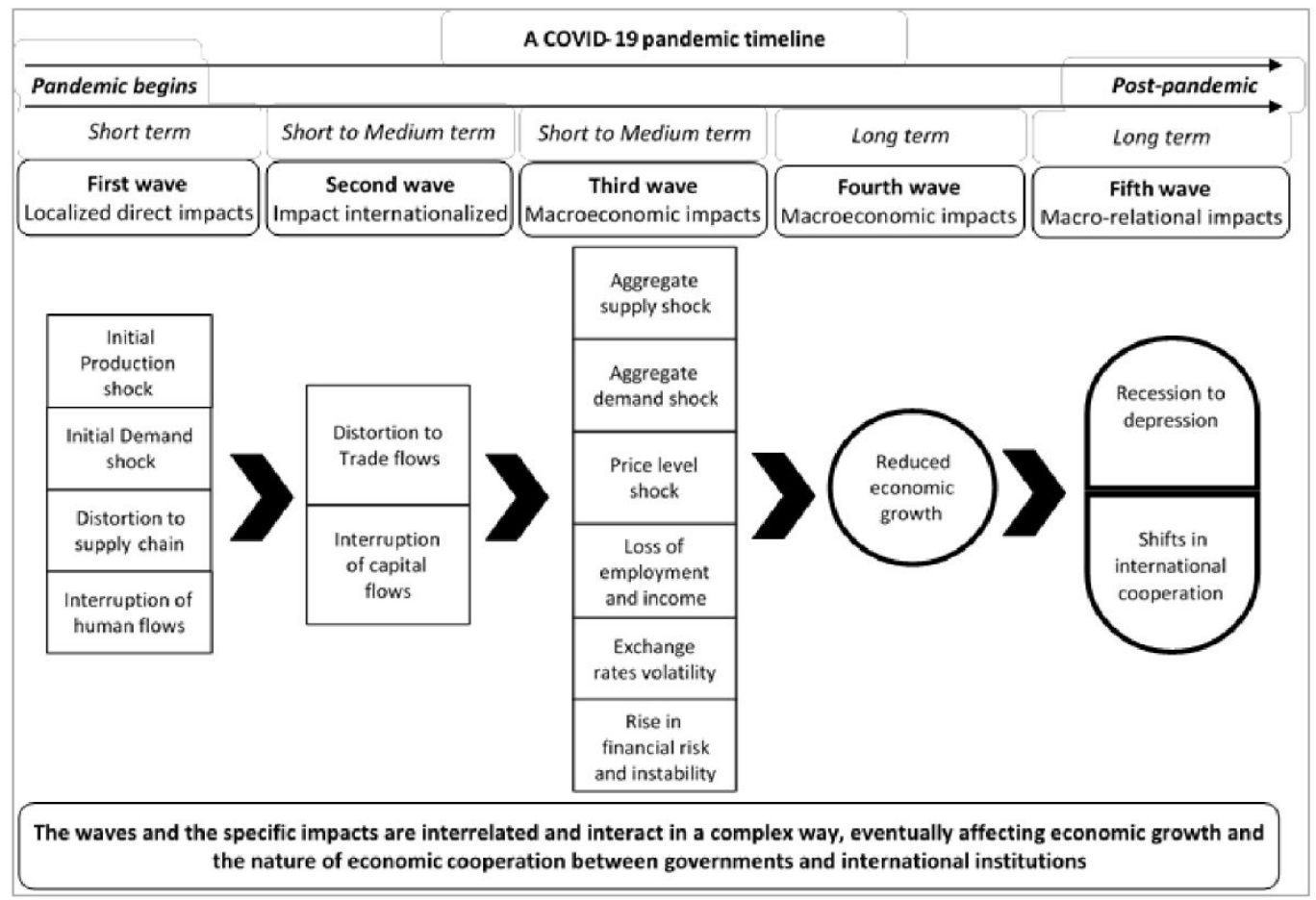

Figure 1 General Mapping of The Possible Economic Impacts of the COVID-19 Source: (Barua, 2020)

This research is expected to enrich the scientific reference for event-studies on noneconomic events and their direct impact on the capital market in Indonesia generally and the impact of reactions on the related industrial sector, but still paying attention to the robustness of research results through a critical review of similar research on the impacts COVID-19 among other countries.

Through this research, it is hoped that investors will be able to recognize the behavior of the Indonesian stock market better so that they can make the best investment decision in every event (economic and non-economic) that occurs.

In this study, the hypothesis to test is whether there is a difference in sectoral abnormal return ( $A B R$ ) and cumulative abnormal return (CABR) on the Indonesian stock exchange before and after the announcement of the first case of positive COVID-19 patients in Indonesia on March 2, 2020.

$\boldsymbol{H}_{1}$ : the difference in sector-i abnormal return index was found before and after the announcement of the first positive patient case for COVID-19 in Indonesia on March 2, 2020. 


\section{Research Method}

The research method used in this research is the event study methodology (ESM). This method is used to take a closer look at the Indonesian stock market's reaction to the COVID-19 pandemic. The event study methodology uses an abnormal return approach so that it can be observed whether the market reaction in obtaining an abnormal return from stock market movement is affected by this pandemic event. The data used in this study are secondary in the form of sectoral indices on the Indonesia Stock Exchange, which are the sectors of Agriculture (SxAGRI), Mining (SxMNG), Basic Industry (SxBSC), Miscellaneous (SxMCL), Infrastructure (SxINF), Financial ( SxFNC), Trading (SxTRD) and Manufacture (SxMNF). The research data is sourced from the sectoral index of the Indonesia Stock Exchange from January - March 2020. The observation period was carried out for 10 days before and 10 days after the announcement of the first COVID-19 case in Indonesia, March 2, 2020. Data analysis techniques will use the paired test. sample t-test on abnormal return before and after the event.

This study uses two methods to calculate the abnormal return. Actual return is the return that occurs and is received by the investor in the current period compared to the previous day, either in the form of capital gain or capital loss. Actual return calculation uses the current closing index compared to the previous day's closing index which is calculated by equation (1) as follows:

$$
R_{i, t}=\frac{p_{i t}-P_{i t}-1}{P_{i t}-1}
$$

The expected return is the stock return expected by the investor in the future. The calculation of expected return uses the Single Index Market Model based on the price of securities that fluctuate in the direction of the market price index, which is proxied by the Composite Stock Price Index (IHSG) as shown in equation (2) as follows:

$$
R m_{t}=\frac{\sum_{t=-10}^{+10} R_{\mathrm{i}, t}}{21}
$$

Abnormal return from sectoral index (i) on the day - $t$ with equation 3 below

$$
A R_{i, t}=R_{i, t}-R m_{t}
$$

$\mathrm{Ri}$ is the average return of the 10 indexes studied on day t. $\mathrm{Rm}$ is the average return index during the estimated range $(-10,+10)$.

Furthermore, the stock market reaction is identified by comparing the results of the abnormal return calculation from equation 3 above (and the likes, for example, the mean-adjusted return as (Brown \& Warner, 1985)) against the calculation results of the market model method as one of them was developed (Dodd \& Warner, 1983) with the equation (4) below.

$$
A M R_{i, t}=R_{i, t}-\left(\alpha_{i, t}+\beta_{i, t} R m_{t}\right)
$$


Where Rmt is the return of the Composite Stock Price Index. $\alpha_{i, t}$ and $\beta_{i, t}$ are the coefficients obtained from the OLS regression during the estimation window $(-10,+10)$. From the results of the calculation and presentation of the graphs of equation (3) and equation (4), the hypothesis to be tested in this study is that there is no difference between cumulative mean-adjusted abnormal return and cumulative market model method before and after the announcement of confirmed cases. COVID-19 on March 2, 2020 , in Indonesia.

\section{Result and Discussion}

The Indonesia Stock Exchange (BEI) oversees 688 listed issuer companies consisting of 10 industrial sectors; Agriculture, Mining, Basic Industry and Chemical, Miscellaneous Industry, Consumer Goods Industry, Property, Infrastructure, Finance, Trading and Manufacture. Figure 2 shows the 10 sectoral movements in the Indonesia Stock Exchange. The index movement did not fluctuate too much during the study period, which was up on February 17, 2020 to March 16, 2020. The President of Indonesia announced the first positive patient case for COVID-19 in Indonesia on March 2, 2020. The index movement 10 days before the event announcement did not appear to experience too much difference or it can be said that the movement went slope. However, after the announcement, there was a sectoral index market movement in the Indonesian stock market, which was reflected when sectoral movement descended.

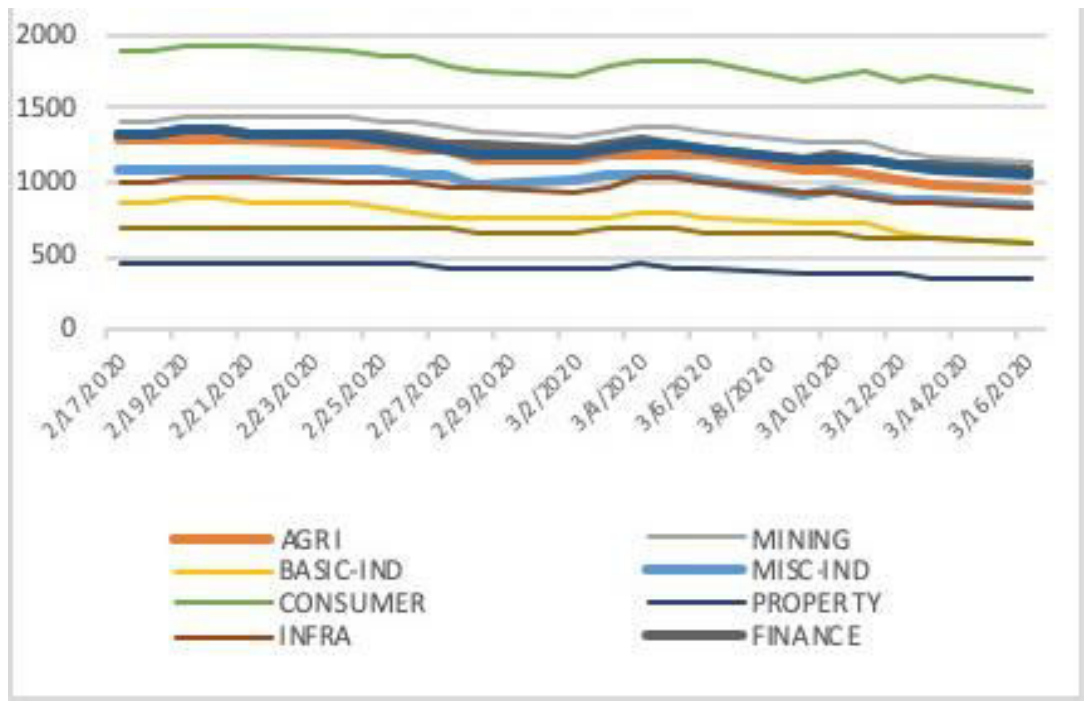

Figure 2 Sectoral Index

Source: Yahoo Finance (accessed at Mei 2020)

The mean-adjusted abnormal return ( $A B R$ ) and cumulative abnormal return (CABR) for the two models used are illustrated in Figure 3 for the IHSG and sectoral movement in the Indonesian stock market. It can be seen from the figure where the CABR shows a quick descending since day 0 when the first confirmed COVID-19 case in Indonesia was announced that shows a greater effect on the return of the stock market. The average 
difference between cumulative returns before and after the event date uses the event range $(-10,+10)$ for the 10 industries sector movement. The results presented in table 1 indicate that there is a statistically significant difference in the mean returns to CAMR at the $99 \%$ confidence level.

Table 1 Mean Equality Test for Cumulative Abnormal Return (CABR)

\begin{tabular}{|c|c|c|c|c|c|}
\hline & \multicolumn{5}{|c|}{ Mean-Adjusted Abnormal Return } \\
\hline $\begin{array}{c}\text { Event } \\
\text { Window }\end{array}$ & Sector & $\begin{array}{c}\text { Before } \\
\text { (\%) }\end{array}$ & $\begin{array}{l}\text { After } \\
(\%)\end{array}$ & $\begin{array}{c}\text { After- } \\
\text { Before (\%) }\end{array}$ & Sig. \\
\hline \multirow[t]{12}{*}{$-10,+10$} & AGR-Agriculture & -0.38 & -0.68 & -0.29 & $0.000 * * *$ \\
\hline & MNG-Mining & 0.18 & -0.08 & -0.26 & 0.415 \\
\hline & BSC-Basic Industry & -0.50 & -0.80 & -0.30 & $0.000 * * *$ \\
\hline & MCL- Miscellaneous & -0.13 & -0.55 & -0.43 & $0.091^{*}$ \\
\hline & $\begin{array}{l}\text { SCM-Consumer } \\
\text { Goods }\end{array}$ & -0.20 & 0.62 & 0.83 & $0.016^{* *}$ \\
\hline & PRO- Property & 0.24 & -0.54 & -0.78 & $0.024 * *$ \\
\hline & INF- Infrastructure & 0.13 & 0.00 & -0.13 & $0.000 * * *$ \\
\hline & FNC-Finance & 0.00 & 0.10 & 0.10 & $0.001 * * *$ \\
\hline & TRD-Trade & 0.21 & 0.09 & -0.12 & $0.000 * * *$ \\
\hline & MNF-Manufacture & -0.29 & 0.00 & 0.29 & 0.277 \\
\hline & IHSG-Composite & -0.72 & -1.28 & -0.55 & 0.586 \\
\hline & \multicolumn{5}{|c|}{ Market Model } \\
\hline $\begin{array}{c}\text { Event } \\
\text { Window }\end{array}$ & Sector & $\begin{array}{l}\text { Before } \\
(\%)\end{array}$ & $\begin{array}{l}\text { After } \\
(\%)\end{array}$ & $\begin{array}{c}\text { After- } \\
\text { Before (\%) }\end{array}$ & Sig. \\
\hline \multirow[t]{10}{*}{$-10,+10$} & AGR-Agriculture & -0.46 & -1.01 & -0.55 & 0.554 \\
\hline & MNG-Mining & 0.90 & -0.87 & $-1.77 \%$ & $0.063^{*}$ \\
\hline & BSC-Basic Industry & 1.62 & 0.17 & -1.45 & 0.127 \\
\hline & MCL- Miscellaneous & 2.30 & 0.20 & -2.10 & 0.104 \\
\hline & $\begin{array}{l}\text { SCM-Consumer } \\
\text { Goods }\end{array}$ & 0.33 & 0.75 & 0.41 & 0.685 \\
\hline & PRO- Property & -1.41 & -1.85 & -0.44 & 0.546 \\
\hline & INF- Infrastructure & -1.22 & 0.94 & 2.17 & 0.123 \\
\hline & FNC-Finance & 0.39 & 0.40 & 0.00 & 0.998 \\
\hline & TRD-Trade & -3.18 & -2.37 & 0.81 & 0.193 \\
\hline & MNF-Manufacture & 1.06 & 0.49 & -0.56 & 0.559 \\
\hline
\end{tabular}

$*, * *, * * *$ represent the confidence level at the $90 \%, 95$, and $99 \%$ levels respectively

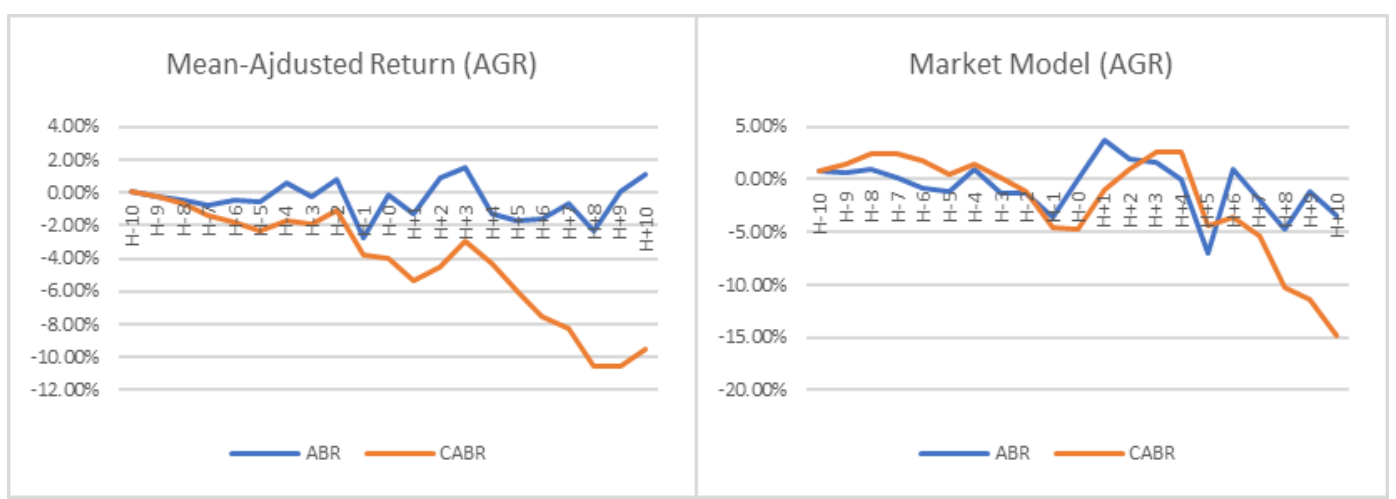

Figure 3 Abnormal Return and Cummulative Abnormal Return 
Trisnowati \& Muditomo

COVID-19 and Stock Market Reaction in Indonesia

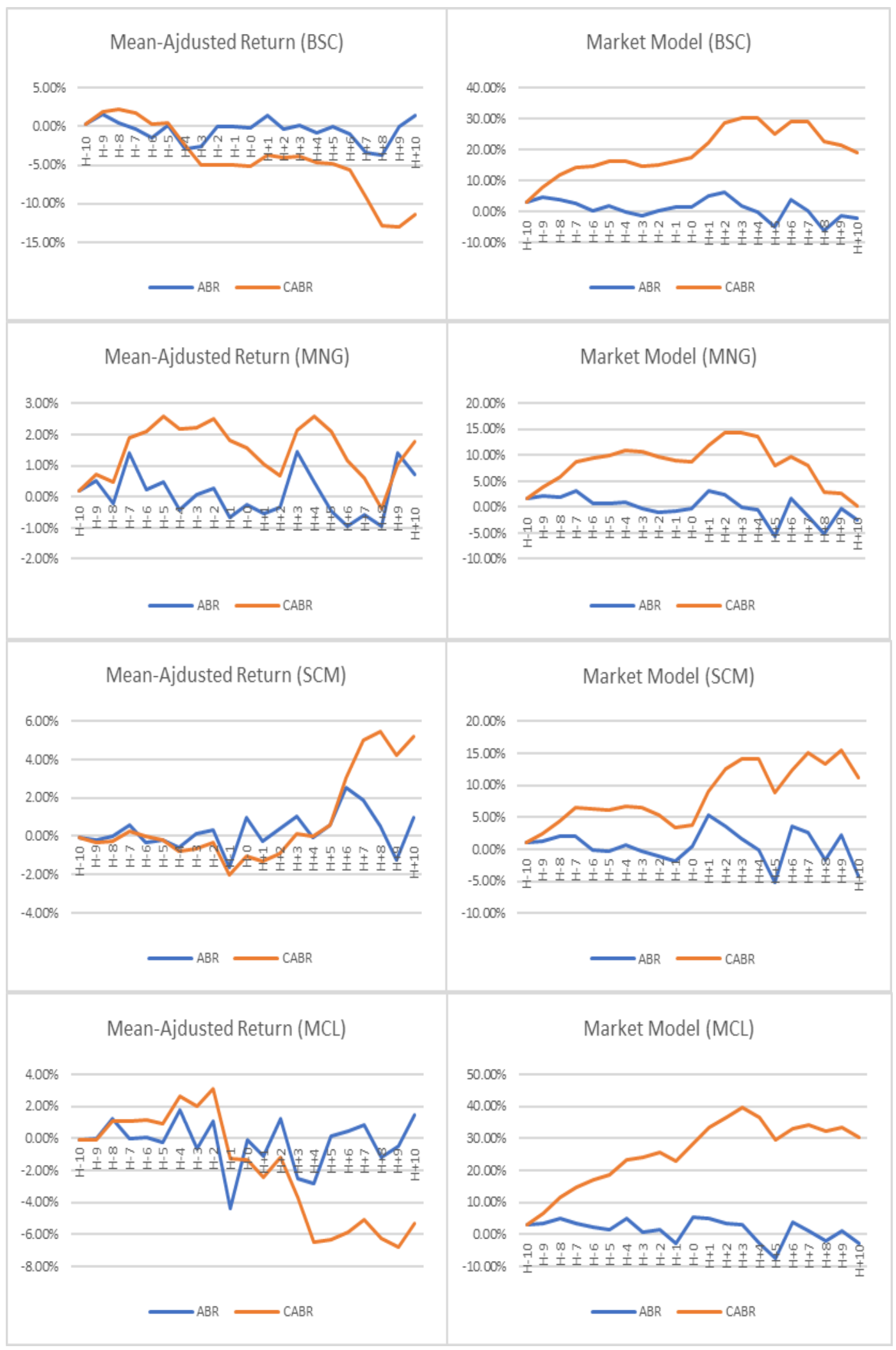

Figure 3 Abnormal Return and Cummulative Abnormal Return (cont') 
Trisnowati \& Muditomo

COVID-19 and Stock Market Reaction in Indonesia

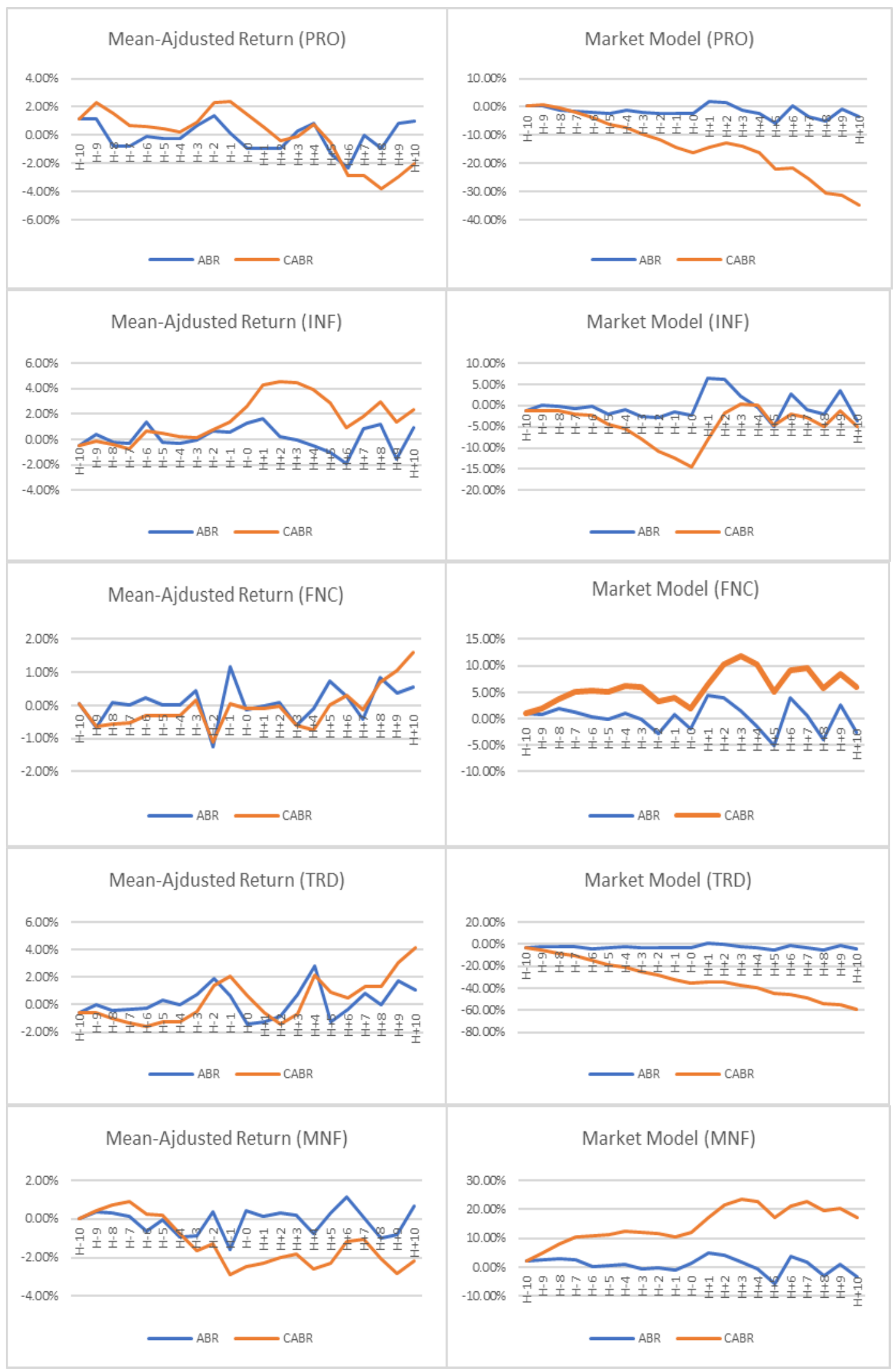

Figure 3 Abnormal Return and Cummulative Abnormal Return (cont') 
The analysis result by paired samples test on the mean-adjusted abnormal return method showed a difference between the Abnormal Return (ABR) values before and after the announcement of the first positive patient case in Indonesia announced by the President.

The results of partial analysis on each sector index show that 8 sectors experienced differences in $A B R$ values before and after the announcement of the first positive patient case. They are agricultural sector (SXAGR); basic and chemical industry (SxBSC); various industries ( $\mathrm{SxMCL}$ ); consumer goods industry ( $\mathrm{SxSCM}$ ); property and real estate (SxPRO); transportation and infrastructure (SxINF); finance (SxFNC); trading, services, and investment (SxTRD). Meanwhile, the mining (SxMNG) and manufacturing (SxMNF) sectors have no difference in ABR values before and after the announcement of the first positive patient case in Indonesia. Analysis with the market model shows that only the mining sector (SxMNG) has a difference in abnormal return before and after the the first case of corona sufferer in Indonesia announced.

The finding on 8 sectors that is proven statistically experiencing the abnormal return in Indonesia stock market is in line with the research result (Baldwin \& Mauro, 2020) in China stock market and USA (Figure 4 and 5) that shows relative responsiveness of stock on the sectors of transportation industry, property, retail, finance/investment and primary industry/chemicals and consumer goods/personal. On the other side the response difference between the stock market in Indonesia and China/AS can be found in the energy sector/mining where the impact towards Indonesia stock market has not been seen yet statistically, when the significant impact is found in China and USA stock market.

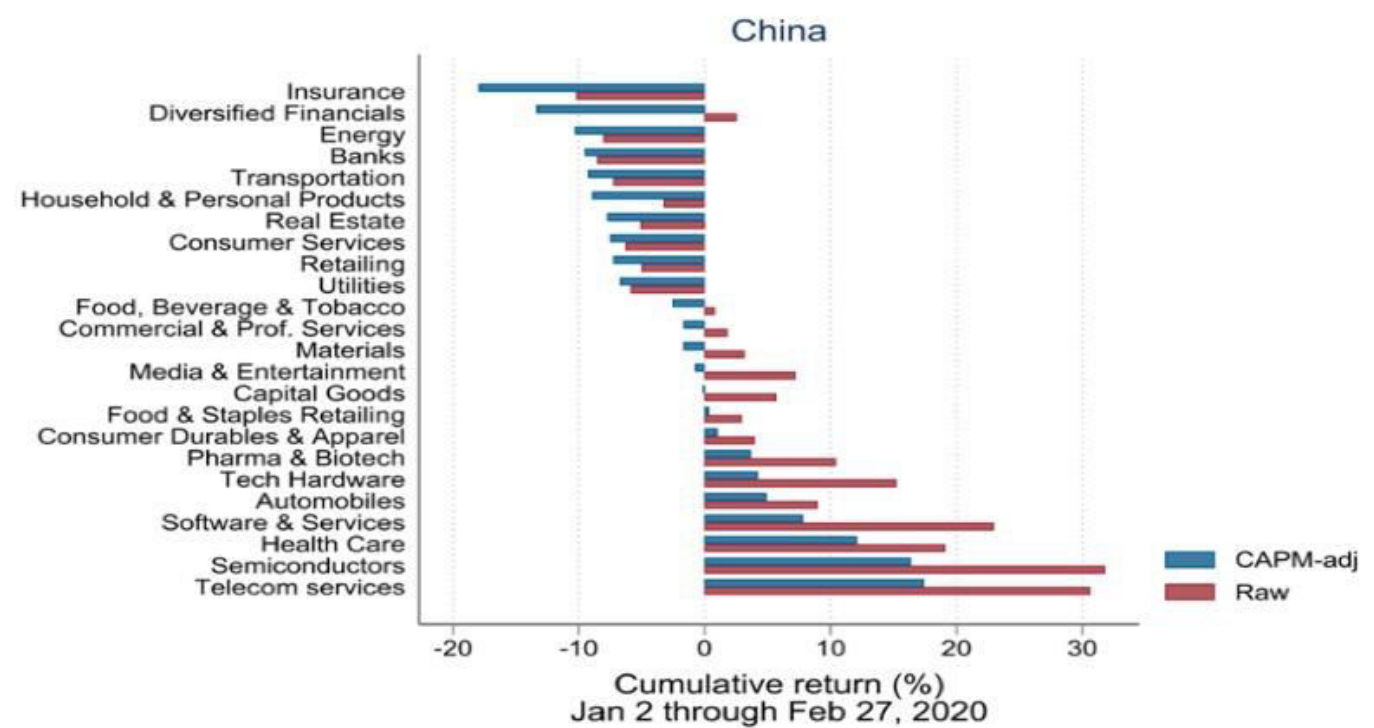

Figure 4 Return of Sector Industry in China during the COVID-19 Pandemic 


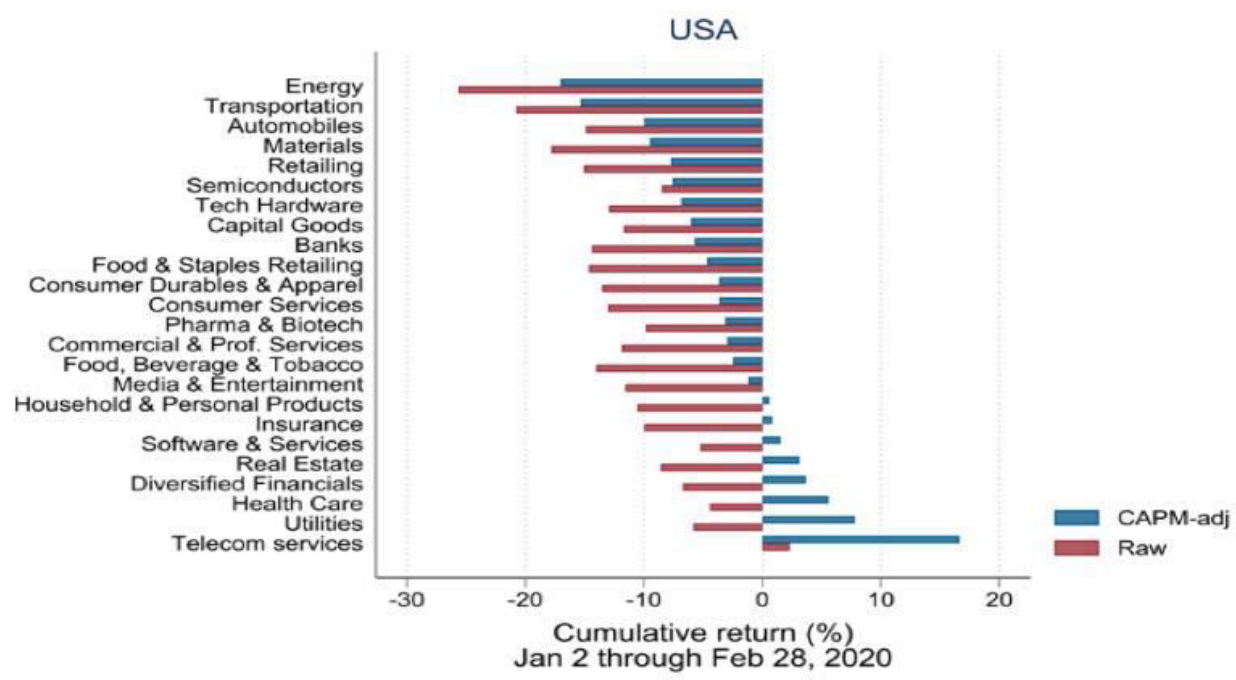

Figure 5 Return of Sector Industry in USA during the COVID-19 Pandemic

This different result shows the expectation gap to the future of company, industry, and market economy reflected from the investor behavior on the stock market (Wagner, 2020). Abnormal return response of the 10 average sectors of stock market industry in Indonesia (0.0057) supports the research (Liu et al., 2020) examining the 21 stock markets response in many countries with abnormal return of Indonesia stock exchange at the number of 0,0069 (absolute).

One of the investors' behaviors during the global pandemic is to avoid the uncertainty (Ashraf, 2020), so the expectation of the future over the industries will influence the investment decision. An investor can use both methods; mean-adjusted abnormal return and market model. From both models, the market model is stronger in depicting the abnormal return achieved because of the market model also counts the risk index and condition of the market index occurred in the stock exchange.

\section{Conclusion}

The analysis result shows that the eight industry sectors in Indonesia which are agriculture industry; primary industry and chemicals; consumer goods; property and real estate; transportation and infrastructure; finance; trading, service, and investment give fast response to the government announcement since the first COVID-19 case in Indonesia on 2 March 2020. This reaction explains that those sectors have observed the direct impact of the pandemic on their industries. They are agriculture sector that will be impacted on the bargain side and agriculture product demand, primary industry sector and chemical will face the demand change of medical product, property sector and real estate will deal with the decreasing demand, transportation sector and infrastructure will experience the descending user potency and new development investment, finance industry will change its transaction volume that all happens since the social distancing is applied and government purchasing priority and household changed because of the 
pandemic. The slower reaction is found in the mining industry, various industry, and manufacture that happen because in short period they haven't been getting the beneficial impact caused by pandemic and still operate to fulfill the market before the pandemic hits. But the analysis result using the market model shows the different abnormal return in mining sector.

This result is in line with the previous research (Ashraf, 2020; Baldwin \& Mauro, 2020; Liu et al., 2020; Wagner, 2020) that in the first period of COVID-19 pandemic happened globally, affected industrial sectors related to supply chain, and investor's expectation to the future of certain industry post-pandemic, while in the mid and long term industry will be adapting with the behavioral change of consumer expenditures that will prioritize the primary goods for the daily needs (Pratomo, 2020). This result has beneficial value for investor to understand the stock market behavior in giving response to noneconomic events so investor will take the best investment decision on the economic and non-economic events that might happen in the future.

\section{References}

AlAli, M. S. (2020). The effect of who COVID-19 announcement on Asian Stock Markets returns: an event study analysis. Journal of Economics and Business, 3(3), 1051-1054. https://doi.org/10.31014/aior.1992.03.03.261

Alam, M. N., Alam, M. S., \& Chavali, K. (2020). Stock market response during COVID-19 lockdown period in India: An event study. Journal of Asian Finance, Economics and Business, 7(7), 131-137. https://doi.org/10.13106/jafeb.2020.vol7.no7.131

Andarini, D., \& Rahardjo, T. (2016). Analisis reaksi pasar modal terhadap perubahan harga bbm (event study kenaikan dan penurunan harga BBM pada perusahaan food and beverages yang terdaftar di Bursa Efek Indonesia). Jurnal Ilmiah Mahasiswa Fakultas Ekonomi dan Bisnis, 3(2), 1-20. Retrieved from http://iimfeb.ub.ac.id/index.php/iimfeb/article/view/1840

Ashraf, B. N. (2020). Stock markets' reaction to COVID-19: Cases or fatalities?. Research in International Business and Finance, 5(4), 101-249. https://doi.org/10.1016/j.ribaf.2020.101249

Asshodiqi, A. (2016). Reaksi pasar modal terhadap peristiwa pelantikan Presiden tahun 2014 (event study pada saham LQ45, JII dan SMINFRA18). Jurnal Ilmiah Mahasiswa Fakultas Ekonomi dan Bisnis, 3(2), 21-30. Retrieved from http://iimfeb.ub.ac.id/index.php/jimfeb/article/view/1656

Baker, S. R., Bloom, N., Davis, S. J., Kost, K., Sammon, M., \& Viratyosin, T. (2020). The unprecedented stock market reaction to COVID-19. NBER Working Paper Series. 122. https://doi.org/10.3386/w26945

Baldwin, R., \& Mauro, B. W. di. (2020). Mitigating the COVID economic crisis: act fast and do whatever it takes. Research-based policy analysis and commentary from leading economists. Retrieved from https://voxeu.org/content/mitigating-COVID-economic-crisis-actfast-and-do-whatever-it-takes

Barua, S. (2020). Understanding Coronanomics: The economic implications of the coronavirus (COVID-19) pandemic. SSRN Electronic Journal. 1-45. https://doi.org/10.2139/ssm.3566477 
Bash, A. (2020). International evidence of COVID-19 and stock market returns: an event study analysis. International Journal of Economics and Financial Issues, 10(4), 34-38. https://doi.org/10.32479/ijefi.9941

Brown, S. J., \& Warner, J. B. (1985). Using daily stock returns. The case of event studies. Journal of Financial Economics, 14(1), 3-31. https://doi.org/10.1016/0304$\underline{405 X(85) 90042-\mathrm{X}}$

Dodd, P., \& Warner, J. B. (1983). On corporate governance. A study of proxy contests. Journal of Financial Economics, 11(1-4), 401-438. https://doi.org/10.1016/0304$\underline{405 X(83) 90018-1}$

He, P., Sun, Y., Zhang, Y., \& Li, T. (2020). COVID-19's Impact on Stock Prices Across Different Sectors-An Event Study Based on the Chinese Stock Market. Emerging Markets Finance and Trade, 56(10), 2198-2212. https://doi.org/10.1080/1540496X.2020.1785865

Huo, X., \& Qiu, Z. (2020). How does China's stock market react to the announcement of the COVID-19 pandemic lockdown?. Economic and Political Studies, 1-26. https://doi.org/10.1080/20954816.2020.1780695

Islami, L. N., \& Sarwoko, E. (2012). Reaksi pasar modal Indonesia terhadap pergantian Menteri Keuangan ( event study saham yang terdaftar di BEI ). Modernisasi, 8(1), 44 67. Retrieved from http://ejournal.unikama.ac.id/index.php/JEKO/article/view/206

Liu, H., Manzoor, A., Wang, C., Zhang, L., \& Manzoor, Z. (2020). The COVID-19 outbreak and affected countries stock markets response. International Journal of Environmental Research and Public Health, 17(8), 1-19. https://doi.org/10.3390/ijerph17082800

Luhur, S. (2010). Reaksi pasar modal Indonesia seputar pemilihan umum 8 juli 2009 pada saham LQ-45. Jurnal Keuangan dan Perbankan, 14(2), 249-262. Retrieved from http://jurnal.unmer.ac.id/index.php/jkdp/article/view/971

Nanda, R., \& Saryadi, S. (2017). Reaksi pasar modal Indonesia terhadap kebijakan tax amnesty Indonesia pada saham LQ45 tahun 2016-2017. Jurnal Ilmu Administrasi Bisnis, 6(4), 144-156. Retrieved from https://ejournal3.undip.ac.id/index.php/jiab/article/view/17606

Narjoko, D. (2020). COVID-19 and Southeast and East Asian Economic Integration: Understanding the Consequences for the Future. Economic Research Institute for ASE $A N$ and East Asia, 1-7. Retrieved from https://www.eria.org/uploads/media/policy-brief/COVID-19-and-Southeast-andEast-Asian-Economic-Integration.pdf

Ningsih, E. R., \& Cahyaningdyah, D. (2014). Reaksi pasar modal Indonesia terhadap pengumuman kenaikan harga BBM 22 Juni 2013. Management Analysis Journal, 3(1), 15. Retrieved from https://journal.unnes.ac.id/sju/index.php/maj/article/view/3352

Pratama, I. G. B., Sinarwati, N. K., \& Dharmawan, N. A. S. (2015). Reaksi pasar modal indonesia terhadap peristiwa politik (event study pada peristiwa pelantikan Joko Widodo sebagai Presiden Republik Indonesia ke-7). Jurnal Ilmiah Mahasiswa Akutansi Undiksha, 3(13), 1-11. http://dx.doi.org/10.23887/jimat.v3i1.4754

Pratomo, M. N. (2020, October 1). Prospek pasar sabam: cermati sektor tahan banting. Available at Bisnis Indonesia. Retrieved from https://koran.bisnis.com/m/read/20201001/441/1298915/prospek-pasar-sahamcermati-sektor-tahan-banting

Ruiz Estrada, M. A., \& Lee, M. (2020). How COVID-19 can Affect the Worldwide Stock Markets?. SSRN Electronic Journal. Retrieved from https://doi.org/10.2139/ssm.3591698 
Sari, S. T. (2007). Pengaruh kondisi keamanan dalam negeri terhadap harga saham di Bursa Efek Jakarta (event study peristiwa bom Kuningan). Undergraduate Thesis. Retrieved from http://eprints.ums.ac.id/id/eprint/11343

Suganda, T. R. (2018). Event study, teori dan pembahasan reaksi pasar modal Indonesia. Malang: Seribu Bintang.

Suryawijaya, M. A., \& Setiawan, F. A. (1998). Reaksi pasar modal Indonesia terhadap peristiwa politik dalam negeri (event study pada peristiwa 27 Juli 1996). Jurnal Kelola, 7(18), 137-153. Retrieved from http://ilib.ugm.ac.id/jurnal/detail.php?dataId $=8272$

Utama, C. A., \& Hapsari, L. (2012). Jenis industri, kepemilikan saham asing dan reaksi pasar modal akibat serangan bom teroris. Jurnal Akuntansi dan Keuangan Indonesia, 9(2), 100_ 116. https://doi.org/10.21002/jaki.2012.07

Wagner, A. F. (2020). What the stock market tells us about the post-COVID-19 world. Nature Human Behaviour, 4(May), 1-20. https://doi.org/10.1038/s41562-020-0869-y

Wardhani, L. S. (2012). Reaksi pasar modal Indonesia terhadap peristiwa pemilihan gubernur DKI Jakarta putaran II 2012 (event study pada saham anggota indeks kompas 100). Jurnal Ilmiah Mahasiswa FEB, 1(1), 129-142. Retrieved from https://iimfeb.ub.ac.id/index.php/jimfeb/article/view/171

WHO. (2020). WHO Coronavirus Disease (COVID-19). Retrieved from WHO Coronavirus Disease (COVID-19). Available at: https://COVID19.who.int/?gclid=EAIaIQobChMIzcf9pbSJ7AIVe9xMAh26pQm wEAAYASABEgIykPD BwE

Wibowo, A. (2017). Reaksi investor pasar modal Indonesia terhadap paket kebijakan ekonomi tahap I Jokowi - JK ( Studi pada saham LQ 45 periode Agustus 2015 Februari 2016 ). Media Ekonomi dan Manajemen, 32(1), 58-70. https://doi.org/10.24856/mem.v32i1.452

Xiong, H., Wu, Z., Hou, F., \& Zhang, J. (2020). Which firm-specific characteristics affect the market reaction of Chinese listed companies to the COVID-19 Pandemic? Emerging Markets Finance and Trade, 56(10), 2231-2242. https://doi.org/10.1080/1540496X.2020.1787151

Yuwono, A. (2013). Reaksi pasar modal di bursa efek Indonesia terhadap pengumuman peristiwa bencana banjir yang melanda Daerah Khusus Ibu Kota Jakarta tahun 2013. Nominal, Barometer Riset Akuntansi dan Manajemen, 2(2), 135-150. https://doi.org/10.21831/nominal.v2i2.1668

Zeren, F., \& Hizarci, A. (2020). The impact of COVID-19 Coronavirus on stock markets: Evidence from selected countries. Mubasebe ve Finans Incelemeleri Dergisi, 1, 78-84. https://doi.org/10.32951/mufider.706159 